\title{
История исследований каменных углей и их переработки в Туве
}

\author{
Валерий И. Котельников, Марина П. Куликова, Сергей Г. Прудников \\ Тувинский институт комплексного освоения природных ресурсов Сибирского отделения \\ Российской академии наук, Российская Федерация
}

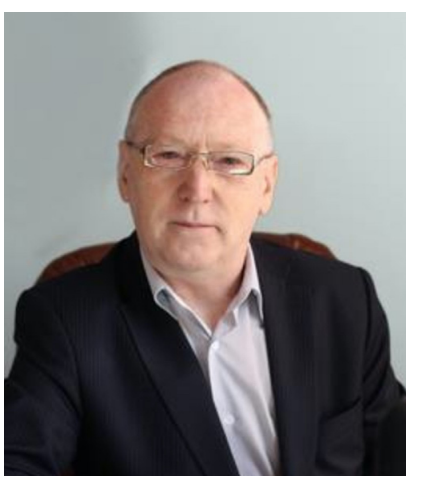

В статье впервые анализируется история исследований каменных углей в Туве: от открытия, изучения и использования каменных углей в качестве топлива до разработки современных научных технологий по глубокой переработке угля. Исследование основано на обширном обзоре научных публикаций, анализе научных разработок Тувинского института комплексного освоения природных ресурсов СО РАН, на внутренних архивных документах института, на воспоминаниях.

В истории геологического исследования Тувы в цзелом и Улуг-Хемского угольного бассейна рассматриваются три периода, которые начинаются с отрывочных сведений географов, топографов и ботаников второй половины ХІХ в. и заканчиваются в 1990-х г2. масштабными исследованиями и разведочными работами. Геологические исследования способствовали систематизации геологических знаний, послужили толчком к росту изученности территории Тувы и вовлечения в хозяйственное использование минерально-сырьевых ресурсов региона. Отмечен вклад отдельных исследователей, в т. ч. А. С. Кола и 3. С. Сат.

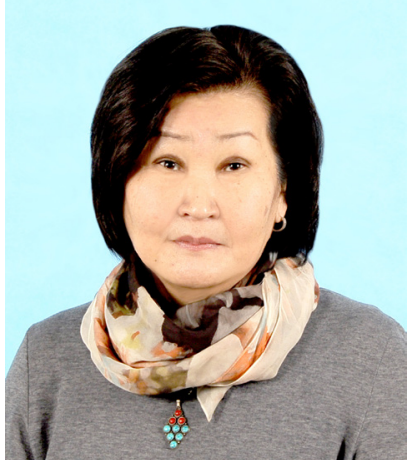

История исследований по переработке каменных углей в Туве рассматривается по этапам: становление лаборатории технологий углепереработки ТИКОПР СО РАН (1987-2002); исследования управляемого изменения свойств угля путём комбинирования методов энергетического и физико-химического воздействия для его активации, разработкой и конструирования нового оборудования для реализации процессов пиролиза, брикетирования каменных углей (2002-2014); обоснование создания углехимического комплекса в Республике Тыва с постепенным переходом на глубокую переработку угля с получением моторных топлив, химических веществ и других ценных продуктов, а также тепловой и электрической энергии (2014 г. - по настоящее время). Перечисляются имена исследователей, диссертационные работы, различные публикации.

Ключевые слова: история науки; история геологии; каменный уголь; переработка

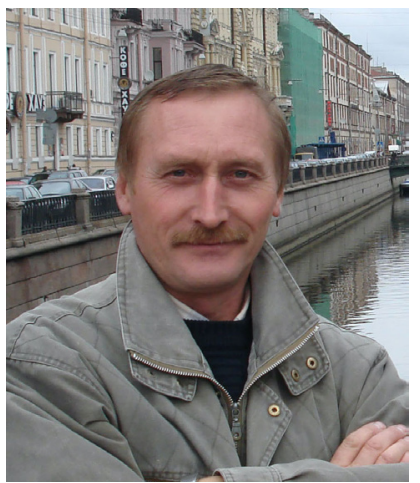
угля; Тува; Ак-оол Серендолович Кол; Зинаида Сотпаевна Сат; ТИКОПР СО РАН

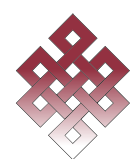

Для цитирования:

Котельников В. И., Куликова М. П., Прудников С. Г. История исследований каменных углей и их переработки в Туве // Новые исследования Тувы. 2020, № 2. С. 225240. DOI: www.doi.org/10.25178/nit.2020.2.16

Котельников Валерий Ильич - кандидат технических наук, директор Тувинского института комплексного освоения природных ресурсов Сибирского отделения РАН. Адрес: 667007, Россия, г. Кызыл, ул. Интернациональная, д. 117А. Тел.: +7 (39422) 6-62-18. Эл. адрес: tikopr@mail.ru ORCID ID: 0000-0001-7481-9770

Куликова Марина Петровна - кандидат химических наук, доцент, старший научный сотрудник химико-технологической лаборатории Тувинского института комплексного освоения природных ресурсов Сибирского отделения РАН. Адрес: 667007, Россия, г. Кызыл, ул. Интернациональная, д. 117A. Тел.: +7 (913) 353-80-28. Эл. адрес: mpkulikova@mail.ru ORCID ID: 0000-0003-2963-814X

Прудников Сергей Григорьевич - кандидат геолого-минералогических наук, заведующий лабораторией геодинамики, магматизма и рудообразования Тувинского института комплексного освоения природных ресурсов Сибирского отделения РАН. Адрес: 667007, Россия, г. Кызыл, ул. Интернациональная, д. 117А. Тел.: +7 (962) 060-96-55. Эл. адрес: prudnikov_s@inbox.ru ORCID ID: 0000-0002-1012-0036

Kotelnikov Valery Il'ich, Candidate of Engineering, Director, Tuvinian Institute for Exploration of the Natural Resources, Siberian Branch, Russian Academy of Sciences. Postal address: 117a Internatsionalnaya St., 667000 Kyzyl, Russian Federation. Tel.: +7 (394-22) 662-18. E-mail: tikopr@mail.ru

Kulikova Marina Petrovna, Candidate of Chemistry, Senior Research Fellow, Laboratory of Chemical Engineering, Tuvinian Institute for Exploration of the Natural Resources, Siberian Branch, Russian Academy of Sciences. Postal address: 117a Internatsionalnaya St., 667000 Kyzyl, Russian Federation. Tel.: +7 (913) 353-80-28. E-mail: mpkulikova@mail.ru

Prudnikov Sergei Grigoryevich, Candidate of Geology and Mineralogy, Head of Laboratory of Geodynamics, Magnetism and Ore Formation, Tuvinian Institute for Exploration of the Natural Resources, Siberian Branch, Russian Academy of Sciences. Postal address: 117a Internatsionalnaya St., 667000 Kyzyl, Russian Federation. Tel.: +7 (394-22) 6-62-18. E-mail: prudnikov_s@inbox.ru 


\title{
The history of coal studies and coal industry in Tuva
}

\author{
Valery I. Kotelnikov, Marina P. Kulikova, Sergei G. Prudnikov \\ Tuvinian Institute for Exploration of the Natural Resources, Siberian Branch, Russian Academy of Sciences, \\ Russian Federation
}

\begin{abstract}
This is the first ever attempt at a history of coal studies in Tuva, from the discovery and first use of coal as a fuel to developing contemporary scientific technologies of deep procession of coal. Our study is based at an in-depth research summary, including the publications of the staffmembers of Tuvinian Institute for Exploration of the Natural Resources, SB RAS. Other sources include documents from the Institute's archive, and memoirs

The history of geological studies of Tuva in general, and the Ulus-Khem coal basin in particular, three periods can be traced, starting from the fragmentary pieces of information provided by the geographers, surveyors and botanists of the latter half of the 19 th century. In 1990s, the latest period was introduced by large-scale prospecting and reconnaissance surveying. Geological exploration helped systematize geological knowledge, stimulated further surveying of the territory of Tuva, and made better economic use of the mineral resources of the region. Special emphasis is placed on the contribution made by prominent scientists, such as A.S. Kol and Z.S. Sat

Traced stage by stage, the history of coal studies as science in Tuva fully starts with the establishment of the Laboratory of coal procession technologies at TIENR SB RAS (1987-2002); followed by the studies of managed modification of properties of coal by combining power and physico-chemical impact to ensure coal activation. New equipment for pyrolysis and pelleting of coal was created (2002-2014). In the last decade, scientists argued in favour of setting up a coal chemical facility in the Republic of Tuva, which would allow a subsequent transfer to deep procession of coal. This, in its turn, would make it possible to produce engine fuel, chemicals and other substances, as well as thermal energy and electricity. The article also focuses on the contributions made by most prominent researchers and their various publications, including dissertations.
\end{abstract}

Keywords: history of science; history of geology; coal; coal procession; Tuva; Ak-ool Serendolovich Kol; Zinaida Sotpaevna Sat; Tuvinian Institute for Exploration of the Natural Resources, Siberian Branch, Russian Academy of Sciences

\section{For citation:}

Kotelnikov V. I., Kulikova M. P. and Prudnikov S. G. The history of coal studies and coal industry in Tuva. The New Research of Tuva, 2020; 2: 225-240. (In Russ.). DOI: www.doi.org/10.25178/nit.2020.2.16

\section{Введение}

История геологических изысканий является важной составной частью истории отечественной науки и техники, в том числе истории науки о Туве. Интересную историю имеет открытие здесь месторождений угля.

Сведений о добыче и использовании каменного угля на ее территории в древнейшие времена не сохранилось. В периоды бронзового и железного века на территории Тувы широко развивалось горнометаллургическое производство, однако для выплавки меди и железа применялся исключительно древесный уголь. При изучении остатков древних металлургических мастерских более позднего возраста (XIII-XIV в.) археологами было найдено много кокса, выжженного, как показали анализы, из угля Элегестского месторождения (Кызласов, 1969). При строительстве новой шахты «Красная горка» на Элегестском месторождении были обнаружены следы деятельности древних тувинских углекопов в виде древних горных выработок - штолен, наклонных шахт. Длина основных стволов достигала 100 метров. В 1880 г. появились первые сведения о наличии запасов каменного угля в Туве.

В 1921 г. Министерством торговли и промышленности Танну-Тувинской Народной Республики (ТНР) были организованы мелкие поисковые работы на уголь для обеспечения нужд Кызыла. В результате этих поисков, организованных на основе опроса местного населения, были открыты Чихачёвское и Эрбекское месторождения. Уголь добывали на Чихачёвском месторождении с 1925 г.

Первая угольная шахта в Туве была заложена в 1938 г. на Эрбекском месторождении и с 1939 г. здесь начали добывать уголь. В 1950 г. в штольне на Эрбекском месторождении произошло возгорание угольного пласта, поэтому с 1951 г. начали добычу угля на шахте «Красная горка» (Элегестское мес- 
торождение). За год было добыто 32293 тонн угля на шахте. Шахта «Красная горка» была закрыта в октябре 1970 г. в связи с запуском угольных разрезов «Каа-Хемский» и «Чаданский».

Каменный уголь составляет силу и богатство Республики Тыва, неизбежное условие и «локомотив» развития всей экономики Тувы на многие десятилетия. В настоящее время в Туве добывают уголь три предприятия: ООО «Тувинская горнорудная компания» (ТГРК), объем добычи угля в 2018 г. составил 656 тыс. т., ООО «УК «Межегейуголь» - 1086,1 тыс. т., ООО «Тувинская Энергетическая Промышленная Корпорация» (ТЭПК) - 24 тыс. т. Уголь используется в энергетических целях, часть угля поставляют на металлургические предприятия России.

Целью статьи является изучение истории исследований каменных углей в Туве от открытия, изучения и использования каменных углей в качестве топлива - до разработки современных научных технологий по глубокой переработке угля, рассмотрение этих двух процессов становления науки как взаимосвязанных.

История открытия и освоения угля в Туве неразрывно связана с историей развития технологических процессов: от примитивного использования угля, прежде всего, как топлива до использования в металлургии и до научных технологических разработок по глубокой комплексной переработке углей с целью получения моторных топлив, химических веществ и других ценных продуктов, а также экологически чистой тепловой и электрической энергии.

Новизна работы состоит в том, что в статье рассматривается и решается проблема становления науки об истории исследований каменных углей. Ранее ряд наших коллег в статьях рассматривал ресурсную базу углей Тувы. Оценивались перспективы добычи угля (Дабиев, 2013), обосновывались техническая возможность и экономическая целесообразность переработки углей в продукцию с высокой добавленной стоимостью топливного и нетопливного назначения (Балакина, Куликова, 2019), анализировались инструменты регулирования развития углепромышленной территории в регионе (там же), исследовались особенности развития и проблемы угольной отрасли (Соян, 2019).

Данное исследование основано на обзоре научных публикаций, анализе научных разработок Тувинского института комплексного освоения природных ресурсов СО РАН (г. Кызыл), на внутренних архивных документах института, на воспоминаниях, в том числе, авторов статьи, работа которых также являются частью истории данной научной отрасли.

\section{Из истории исследований каменных углей в Туве}

В истории геологического исследования Тувы в целом и Улуг-Хемского угольного бассейна Н. И. Лебедев выделил три периода, которые начинаются с отрывочных сведений географов, топографов и ботаников второй половины XIX в. и заканчиваются в 1990-х гг. масштабными исследованиями и разведочными работами (Лебедев, 2007).

Первый период связан с накоплением первых географических и геологических сведений о Туве. Первые достоверные сведения об углях Тувы содержатся в описании путешествия российского географа Григория Николаевича Потанина (1835-1920) во время его второй экспедиции (Монголо-Тувинской) в Центральную Азию 1879-1880 гг. (Потанин, 1883). Началась экспедиция Потанина в июне 1879 г. из с. Кош-Агач, прошла через территорию всей Тувы от хребта Танну-Ола до озера Косо-Гол (Хубсугул) и закончилась в 1880 г. в Иркутске. В составе экспедиции были натуралист и географ А. В. Адрианов и топограф П. Д. Орлов. На левом берегу р. Улуг-Хем, против устья р. Эрбек, Г. Н. Потанин описал пласты песчаника, иногда переходящего в конгломерат и содержащего кусочки каменного угля. Спутник Г. Н. Потанина, А. В. Адрианов посетил выходы угля выше по р. Элегест, и собрал там отпечатки растений, юрский возраст которых был определён профессором И. Ф. Шмальгаузеном (Schmalhausen, 1883).

В 1881 г. А. В. Адрианов, исследуя Северо-Восточный Алтай по поручению Русского географического общества, вновь посетил Туву. В отчёте об этом путешествии он отметил, что область распространения формации, содержащей каменный уголь, значительна: «... Кроме Элегеста уголь встречается и выше по рекам Баин-Голу, Ирбеку - от устья до вершины последнего, на Булуне, на берегу Улу-Хема, при слиянии Енисеев» (Адрианов, 1888: 273).

В 1887 г. состоялась экспедиция в Туву русского этнографа, географа, революционера Дмитрия Александровича Клеменца (1848-1914). (Обручев, 2007). В Туву Клеменц совершил четыре путешествия, но его геологические наблюдения не обработаны и не опубликованы. Хорошо знавший Д. А. Клеменца, В. А. Обручев отмечал, что «среди путешественников-исследователей материка Азии Д. А. Клеменц 
по праву занимает видное место; значение его исследований, к сожалению, уменьшается тем, что большая часть его наблюдений использована для географии и геологии Азии слишком недостаточно» (Обручев, 1917: 34).

В 1892 г. Петербургский ботанический сад и Русское географическое общество организовали путешествие русского ботаника Порфирия Никитича Крылова (1850-1931) в Урянхайскую землю для проведения географических исследований. В путевых заметках он, в частности, пишет: «... В 12 верстах выше с. Усть-Элегест отмечена заключающая угольный пласт сланцеватая глина, над которой залегает мощный пласт песчаника. Глина черновато-серого цвета, с прожилками угля и дурно сохранившимися остатками пластинчатожаберных. В тёмно-серой несколько известковистой глине из висячего бока замечаются чешуйки мусковита и мелкие обугленные растительные остатки. Что касается угля, то он является довольно блестящим, рассыпающимся, несколько сланцеватым» (Крылов, 1903: 140). Небольшая коллекция пород, собранных им на р. Элегест, была описана профессором Горного института А. М. Зайцевым (Зайцев, 1896).

Второй период геологических исследований Тувы начинается с экспедиций И. П. Рачковского и А. И. Педашенко 1903 г. Еще будучи студентами Санкт-Петербургского университета, по заданию Минералогического общества АН и с подачи Д. А. Клеменца, они исследовали Западную Монголию и Туву. Начинающие исследователи собрали большой петрографический и палеонтологический материал, обрабатывавшийся в последующие годы палеонтологом Н. Н. Смирновой. В частности, она описала растительные остатки из угленосных отложений по р. Улуг-Хем и определила их каменноугольный возраст (ярус урса) (Смирнова, 1912).

Работа Ивана Петровича Рачковского в Монголии и Туве продолжалась более трех десятилетий. В 1917 г. И. П. Рачковский и А. И. Педашенко были направлены в Туву Геологическим Комитетом для осмотра месторождений полезных ископаемых и разработки плана её систематических исследований. Перевалив через Западный Саян, они прошли по р. Элегест и дважды пересекли маршрутами хр. ТаннуОла. В пределах полосы, освещённой маршрутами, были осмотрены золотоносные площади и выходы каменных углей. По их мнению, в геологическом отношении Урянхайский край является естественным продолжением прилегающих к нему участков Западного Саяна и Алтая. Возраст угленосных отложений они считали каменноугольным, отмечали, что пласты каменного угля выходят на дневную поверхность в трёх местах по р. Бий-Хем и в одном - по р. Элегест (Рачковский, Педашенко, 1918).

В 1920 г. И. П. Рачковский с сотрудниками 3. А. Лебедевой и М. Ф. Нейбург по заданию Геологического Комитета работали, главным образом, в области нижнего течения р. Бий-Хем. Они обнаружили 7 выходов угля, три из которых были уже известны и эксплуатировались кустарным способом (Рачковский, 1920).

В 1906, 1907 и 1909 гг., в связи с предполагаемым открытием русского пароходства на верхнем плёсе Енисея, Туву посетила партия инженера Вс. М. Родевича. Касаясь естественных богатств, он пишет: «... область каменного угля простирается от р. Бегреды до Элегеста (около 100 вёрст). Пласты его выходят на берегу р. Тапсы» (Родевич, 1912: 12).

В 1908 г. географ Б. К. Шишкин совершил поездку в Туву для её географического описания и ботанических исследований. В его отчёте отмечено «мощное месторождение» каменного угля в системе р. Бий-Хем (Шишкин, 1914: 109).

В 1914 г. в свет вышла книга Г. Е. Грумм-Гржимайло «Западная Монголия и Урянхайский край. Описание этих стран», в которой автор пишет, что каменный уголь распространён по рр. Бий-Хем и Улуг-Хем (от р. Бегреда до р. Баян-Гол) и обнажается также в долинах рр. Эрбек и Элегест, в местности «Вилланы» и в 3-х верстах от устья р. Тапса (Грумм-Гржимайло, 1914: 537).

В 1917 г. по инициативе профессора И. И. Седергольма финским правительством была организована этнографическая экспедиция в Туву (Урянхайский край), в которой приняли участие О. Баклунд, С.Фосли, Х. Хаузен и Т.Бреннер. Экспедиция также занималась изучением геологического строения верхней части бассейна р. Каа-Хем и средней части хр. Танну-Ола, позже в 1918 г. Х.Хаузен и М.Сандстрём продолжили исследования в долине Енисея (между Кызылом и Джакулем). В обобщающей работе Х. Хаузена ${ }^{1}$ дано схематичное описание геологии Западного Саяна, Урянхайской степи и хр. Танну-Ола, отмечен весьма заметный контраст между хребтами и бассейнообразной областью Урянхайской степи не только в морфологическом отношении, но и по

${ }^{1}$ Хаузен, Х. (1950) Геологический очерк Урянхая или Танну-Тувинской республики : рукопись / пер. Н. Предтеченской. Красноярск : ТФГИ по Сибирскому федеральному округу. № 3366, 14 л. 
литологическому составу и возрасту геологических образований. Впервые выделена выполняющая Урянхайскую депрессию платформенная формация (table land formation), верхним членом которой являются породы песчаниково-сланцево-конгломератовой серии с прослоями угля в различных горизонтах, охарактеризованы отдельные выходы угольных пластов на поверхность: «... Угольные пласты выступают в эрозионных обрывах вдоль Улу-Хема и Элегеста, а также в нижней части Бей-Хема. Точно против слияния Бей-Хема и Ха-Хема имеется несколько тонких пластов угля, разрабатываемых жителями г. Красный. Мощность рабочего пласта только 70 см. Пласты аллохтонного происхождения. Месторождения определённо могут считаться большими, чем местного значения» ${ }^{2}$ Хаузен, отмечая сходные элементы в строении Минусинской и Урянхайской депрессий, считал возраст угленосных отложений, выполняющих последнюю, нижнекаменноугольным.

Третий период начинается с конца 1944 г., когда Тува вошла в состав СССР и на всей ее территории разворачиваются планомерные поисковые и разведочные работы, в первую очередь на уголь в пределах Улуг-Хемского бассейна с участием экспедиций Министерства геологии, Академии наук СССР и других организаций. В частности, в 1945 г. геолог А. И. Архангельский произвёл разведку Эрбекского месторождения, беглое обследование других угольных месторождений Тувы, подсчитал прогнозные геологические запасы угля по Улуг-Хемскому району, составившие 13,6 млрд. т., а также рассмотрел вопросы условий угленакопления ${ }^{2}$.

В этом же году Западно-Сибирским филиалом АН СССР на территории Тувы проводятся геологосъёмочные работы. Академик В. А. Кузнецов отмечает, что юрская угленосная формация несогласно залегает на различных толщах среднего и нижнего палеозоя и слагает обширную плоскую мульду площадью до 2000 км² в области слияния рек Бий-Хем и Каа-Хем и небольшие, уцелевшие от денудации островки в западной части Тувинской котловины у подножия хр. Танну-Ола (Кузнецов, 1946).

В 1946 г. под руководством геолога А.Л. Лосева приступила к работе Улуг-Хемская партия Красноярского геологического управления, которая в 1947 г. на площади развития юрских угленосных отложений производила съёмку масштаба 1:200 $000\left(3000 \mathrm{kM}^{2}\right)^{3}$. Были опробованы угли известных месторождений и составлена геологическая карта наиболее крупной угленосной площади (Кызылской). Геологические запасы углей определены в 7363 млн т. ${ }^{4}$ А. Л. Лосев впервые даёт определение УлугХемскому бассейну: «... Самая крупная площадь осадков угленосной юры, характеризующей эту депрессию, занимает её восточное окончание - область слияния рек Бий-Хема и Каа-Хема, а также район незначительного отрезка верхнего течения Енисея (Улуг-Хема). Размеры этого поля, почти сплошного распространения угленосных пород, превышающие 2500 км², и весьма значительные (свыше 5 млрд т) запасы угля, характеризующие осадки средней юры, позволили именовать данный контур каменноугольным бассейном (Улуг-Хемский каменноугольный бассейн)...» ${ }^{5}$

В результате проведенных работ в период 1945-1956 г. были установлены основные черты геологического строения и угленосности Улугхемского каменноугольного бассейна, определены петрографические типы, марочный состав, качество, степень метаморфизма и технологические свойства углей, проведена детальная разведка участков Каа-Хемского, Эрбекского, Межегейского и Элегестского месторождений с подсчётом запасов угля.

С 1958 по 1980 гг. работы по изучению угленосности бассейна практически не проводились, за исключением обобщений ранее проведённых исследований, поисковых работ в районе Чихачёвского месторождения и доразведки участков под открытую разработку на Каа-Хемском месторождении в начале 1960-х и 1970-х годов (Лебедев, 2007).

\footnotetext{
${ }^{1}$ Хаузен, Х. (1950) Геологический очерк Урянхая или Танну-Тувинской республики: рукопись / пер. Н. Предтеченской. Красноярск : ТФГИ по Сибирскому федеральному округу. № 3366, 14 л.

${ }^{2}$ Архангельский, А. И. (1945) Отчёт по геолого-разведочным работам на каменный уголь, произведённым в Тувинской АО в 1945 г. / рукопись. СПб. : Фонды ВСЕГЕИ. 221 с.

3 Лосев, А. Л. (1948) Геологическое строение и угленосность Кызылской угленосной площади Улуг-Хемского каменноугольного бассейна / отчёт о геол.-поисковых работах Улугхемской партии в 1946 и 1947 гг. / геол. отчет. Красноярск : ТФГИ по Сибирскому федеральному округу, № 615. - 121 л.

${ }^{4}$ Лосев, А. Л. (1949) Геологическое строение и угленосность правобережной части Кызылско-Эрбекской мульды Улуг-Хемского каменноугольного бассейна / геол. отчет Улугхемской геол.-съёмочной партии треста «Востсибуглегеология» по результатам работ 1948 г. : рукопись. Красноярск, ТФГИ по Сибирскому федеральному округу, № 620.230 с.

5 Лосев, А. Л. (1952) Отчёт о геологоразведочных работах, проведённых в 1949-1952 гг. на участках 1-2 Эрбекского каменноугольного месторождения / геол. отчет. Красноярск, ТФГИ по Сибирскому федеральному округу, № 160701.160 c.
} 
С 1981 г. в Улуг-Хемском бассейне крупномасштабные поисково-разведочные и исследовательские работы на угли возобновляет Тувинская геологоразведочная экспедиция. Большим коллективом геологов экспедиции (Р. Т. Уссар, В. И. Шибанов, А. А. Семеряков, И. Я. Фаткулин, В. П. Алексеев, В. И. Вялов, И. Ю. Яковлев, О. Ф. Володарский, Н. Е. Дубовик, В. А. Круглов, В. В. Фромм, В. Н. Криканов, В. В. Блинников, В. В. Михайлов, В. А. Габеев и др.) была изучена угленосность почти всей площади бассейна, установлена максимальная глубина залегания пласта 2.2-Улуг, выявлено 80 пластов угля, изучены вещественный состав, технологические свойства и качество углей, подсчитаны прогнозные ресурсы. Проведены геофизические, гидрогеологические и инженерно-геологические исследования всей площади бассейна (Лебедев, 2007).

Из исследователей этого периода необходимо выделить первых тувинских инженеров-геофизиков по специальности и супругов по жизни Ак-оола Серендоловича Кола (1942-2015) (фото 1) и Зинаиду Сотпаевну Сат (род. 1943) (фото 2).

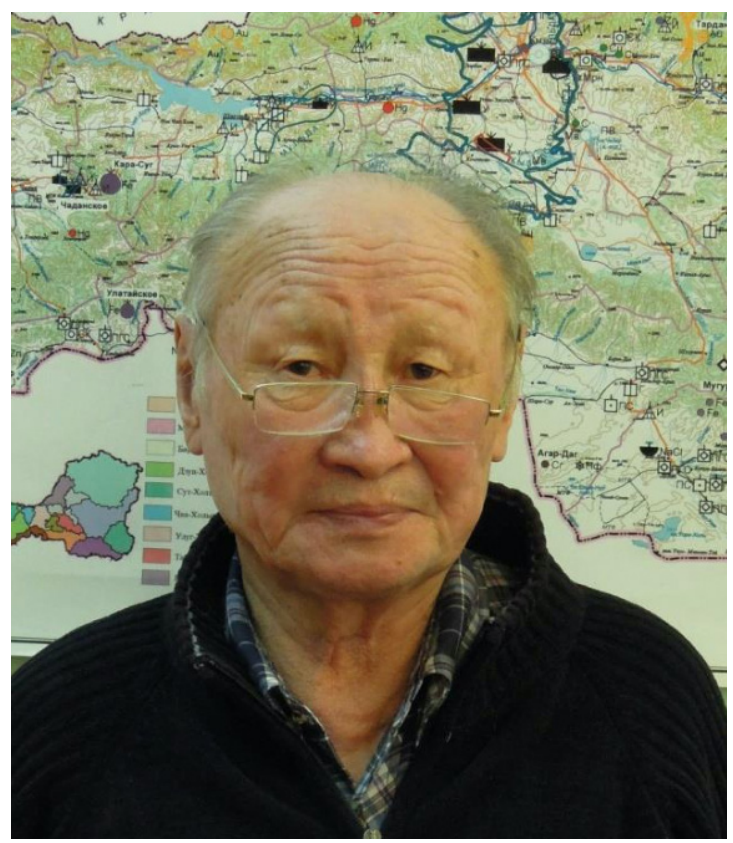

Фото 1. Почетный разведчик недр геофизик Ак-оол Серендолович Кол. Фото 2009 г. из архива 3. С. Сат. Serendolovich Kol. Photo courtesy Z. S. Sat, 2009. Photo 2. Honorary prospector, geophysicist Ak-ool

В 1981-1982 гг. А. С. Кол в качестве начальника Геофизической партии занимался разведкой Чангыз-Хадынского месторождения каменного угля. Работы проводились в соответствии с планом геологоразведочных работ Тувинской ГРЭ в развитие приказа Мингео СССР. В нем, в частности, предписывалось: «выявить и разведать к 1984 году для местных нужд в районе Чаданского угольного месторождения участок, пригодный для открытой добычи, с запасами не менее 6 млн тонн» ${ }^{1}$. В связи с тем, что западные районы Тувы обеспечивались углем за счет Чаданского месторождения, обладающего в целом ограниченными запасами топлива. Проведенные на Чангыз-Хадынской площади в непосредственной близости к разрабатываемому Чаданскому месторождению геологоразведочные работы позволили удвоить запасы каменных углей, пригодных для открытой разработки.

Судьба Ак-оола Серендоловича Кол неразрывно связана с геологическим изучением недр родной Тувы. Родился он в Тодже, в 1960 г. окончил Тора-Хемскую школу. Школьные годы прошли, как и у всех местных ребят 19501960 гг.: зимой учеба, спорт, летом помогал родителям на сенокосе, пас оленей в гольцовой зоне в верховьях р. Серлиг-Хем. Там впервые увидел полевой труд геологов, поскольку лагерь геологов располагался рядом с оленеводческой стоянкой. Помогал в транспортировке их грузов на оленях, так как олени в условиях скал, курумов, болот справляются с перевозками лучше лошадей. Работа запомнилась молодому парню.

После 10-го класса работал в колхозе. Через год призвали в армию. Отслужил 3 года в Германской демократической республике (ГДР). После этого окончил геологоразведочный факультет Томского политехнического института. По распределению в качестве инженера-геофизика приехал в Кызыл в Тувинскую геологоразведочную экспедицию Красноярского Геологического Управления. Успел только 2 года проработать в полевой партии, как призвали вторично в армию. Отслужил 2 года в Монгольской Народной Республике (МНР).

В 1973 г. вернулся в Тувинскую геологоразведочную экспедицию и с тех пор работал в геологической отрасли родной Тувы, пройдя путь от геофизика до председателя Комитета геологии и недропользования по Республике Тува Роскомгеологии.

За это время пришлось побывать во всех уголках Тувы, на геолого-съемочных работах, поисках и разведке месторождений разных полезных ископаемых, углей, питьевых подземных вод для чабанских стоянок. Такой широкий спектр выполняемых работ был связан с тем, что специализацией являлись

${ }^{1}$ Лешаков, Э. И., Баталова, Л. С. (1983) Предварительная разведка южного участка Чангыз-Хадынского месторождения каменного угля / геол. отчет. Кызыл : Тывинский филиал ФБУ «ТФГИ по Сибирскому федеральному округу», № 1744.77 с. 
геофизические методы изучения недр. Геофизиков бросали на помощь геологам, гидрогеологам, геохимикам занятым поисками самых разных полезных ископаемых. Для этого в Тувинской ГРЭ в 1980 г. была создана специализированная Геофизическая партия, которую и возглавил А.С. Кол. Партия состояла из нескольких отрядов, занимавшихся электроразведочными, магниторазведочными, гравиразведочными, радиометрическими работами. Обслуживаемые геофизиками геологические партии, в иные года их число доходила до 11, были разбросаны по всей Туве, поэтому подчас за один полевой сезон приходилась поработать на участках недр расположенных от Монгун-Тайги до Тоджи, от степей южных кожуунов до таежных Саян. Такая специфика работы позволила на практике ознакомиться геологическим строением большинства месторождений Тувы. В то время кадровый состав Тувинской геологоразведочной экспедиции был очень сильным. Руководство республики ценило и всегда поддерживало геологов. К примеру, по инициативе руководства республики депутатом Верховного Совета СССР от Тувы в 1980-х гг. был избран министр геологии СССР Е. А. Козловский, который за время своего депутатства очень сильно помог Туве не только в плане расширения геологоразведочных работ на территории республики, но и в развитии строительной и сельскохозяйственной отраслей. Были разведаны крупные Ак-Сугское, Улуг-Танзекское, Баян-Кольское месторождения цветных и редких металлов, запасы и ресурсы каменных углей Улуг-Хемского угольного бассейна были доведены до 13,5 млрд. т., наращены запасы полиметаллических руд Кызыл-Таштыгского месторождения. Открыто Кара-Белдирское и разведаны запасы Тарданского месторождений рудного золота, разведаны запасы россыпного золота Алгиякского, Билелигского, р. Черного, Эмийского месторождений. Практически во всех кожуунах были разведаны запасы глин для кирпичного производства, определена сырьевая база для производства цемента, керамзита, стекла, минеральной ваты. Интенсивно велось бурение на подземные воды для обводнения пастбищ отгонного животноводства. Были оценены запасы цеолитов для удобрений и добавок в корм скота и птицы, ресурсы фосфоритов для удобрений. Таким образом, геологи и геофизики создали минерально-сырьевую базу для устойчивого развития Тувы и Отечества в целом.

В 1991-1992 гг. Ак-оол Серендолович Кол - заместитель министра природных ресурсов и экологии Республики Тува по геологии. В 1992-1997 гг. председатель Комитета геологии и недропользования по Республике Тува Роскомгеологии. В 1997-2002 гг. - ведущий специалист Управления природопользования и экологии Республики Тува. В 2005-2013 гг. - эксперт Управления по недропользованию Тувы.

Выдающийся труд Ак-оол Серендоловича был отмечен наградами: Знак «Отличник разведки недр», почетная грамота Верховного Совета Тувинской АССР (1979), орден «Дружбы народов» (1983), звание «Почетный разведчик недр» (2007).

Совместно с Ак-оолом Серендоловичем геофизическими поисками углей занималась Зинаида Сотпаевна Сат - первая женщина-тувинка, геофизик в Туве, внесшая весомый вклад в дело геологического изучения недр в Республике Тыва. Ей присвоено почетное звание «Ветеран труда» ПГО «Красноярскгеология» в 1989 г.

3. С. Сат начала свою трудовую деятельность в должности инженера-геофизика в Тувинской геологоразведочной экспедиции Красноярского Геологического Управления в 1969 г., после окончания Томского политехнического института. С того времени по сей день она работает в от-

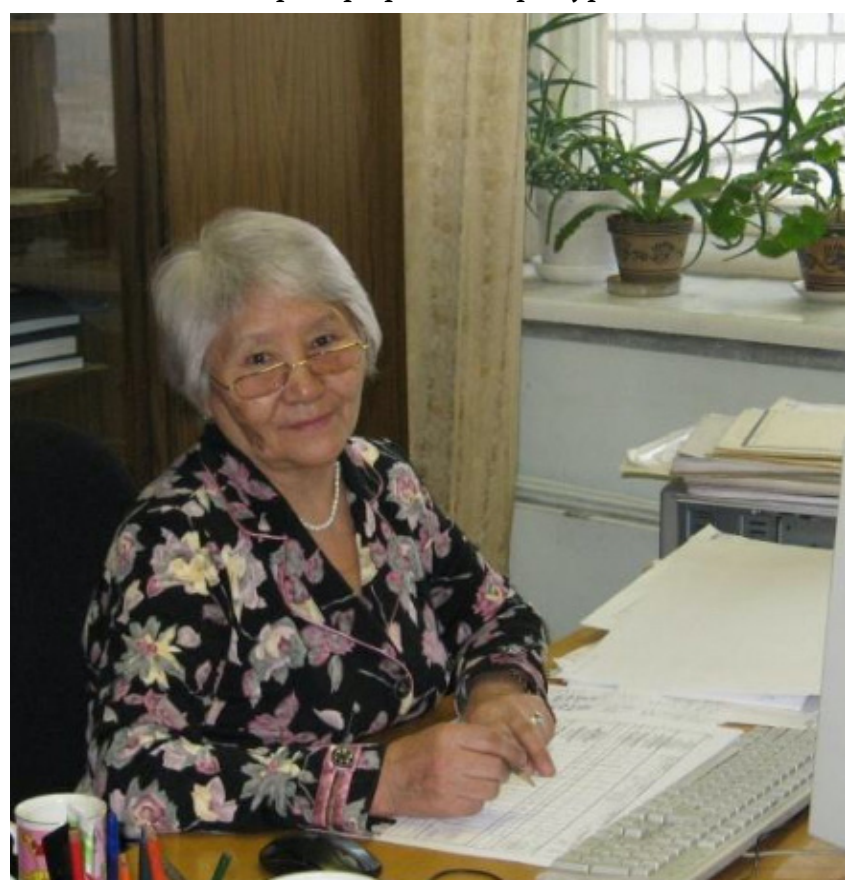

Фото 2. Геофизик Зинаида Сотпаевна Сат. Фото 2008 г. из архива 3. С. Сат. Photo 3. Geophysicist Zinaida Sotpaevna Sat. Photo courtesy of herself, 2008. расли геологии. Первые несколько лет работала геофизиком в Ондумской, Тапсинской, Чыргакской поисково-геологических партиях, проводила геофизические исследования в полевых условиях методами магниторазведки, электроразведки (в различных модификациях), радиометрии и геохимии, принимала участие в написании геофизических 
глав и камеральной обработке материалов с составлением необходимых карт и других графических материалов для геологических отчетов.

В 1973-1974 гг. принимала участие в разведке Саянского месторождения хризотил-асбеста, работала в камеральной группе обработки полевых материалов, за добросовестный труд в числе других была награждена Бронзовой медалью ВДНХ СССР. С 1980 г., после организации Геофизической партии, работала сначала старшим, а затем - ведущим геофизиком партии. По результатам геофизических исследований партии открыты, подтверждены и расширены перспективы многих месторождений и рудопроявлений, таких как Кадыр-Осское, Ажикское молибденово-медные, Новоакхемское кобальтовое, Чангыс-Хадынское угольное, Туннукское ртутное, Баян-Кольское нефелиновое, Кара-Белдирское и Солчурское золоторудные и другие.

С 1994 г. 3. С. Сат переведена из Тувинской геологоразведочной экспедиции на государственную службу в Комитет по геологии и использованию недр Республики Тыва, после реорганизации - в Министерство природных ресурсов Республики Тыва в качестве ведущего специалиста. Затем с 1997 г. начальник Тувинского территориального геологического фонда. С 2000 г. по настоящее время работает в Тывинском филиале ФБУ «Территориальный фонд геологической информации по Сибирскому федеральному округу», начальником отдела геологических фондов.

Под руководством 3. С. Сат ведется большая работа по формированию государственных геологических информационных ресурсов, их хранение, защита и эффективное использование, в первую очередь - по сбору, систематизации и хранению геологических материалов и документов. Ведется учет запасов месторождений полезных ископаемых, регистрация геологоразведочных работ и учет их результатов. Организована работа по внедрению компьютерной техники для автоматизированного ведения баз данных по изученности, кадастра месторождений, баланса запасов, регистрации и учета лицензии на недропользование.

В 1992 г. выполнена переоценка кондиционных ресурсов Улуг-Хемского бассейна и, в частности, Кызылско-Эрбекской мульды, по состоянию на 1.01.1993 г. ${ }^{1}$ (Гаврилин, Антонова, Кочуева, 1993). Разведанные и учтённые Госбалансом запасы каменного угля марок Ж, ГЖ и Г по промышленным категориям сосредоточены главным образом на Кызылской и Эрбекской подсчётных площадях бассейна. Балансовые запасы каменного угля по состоянию на 01.01.2007 г. составляют 3604 млн т., в т. ч. коксующиеся (особо ценные марки) - 3398 млн т. (Государственный ..., 2007). Общие кондиционные прогнозные ресурсы в пределах Кызылско-Эрбекской мульды составляют 13720 млн т, а в бассейне в целом - 15196 млн т. (Гаврилин, Антонова, Кочуева, 1993). Только в окрестностях Кызыла запасы разведанных высококачественных каменных коксующихся и энергетических углей могут обеспечить неограниченные возможности их крупномасштабной, преимущественно шахтной, добычи.

Месторождения каменного угля на территории Тувы относятся преимущественно к Улуг-Хемскому бассейну (до 94\% разведанных запасов) юрского возраста, который включает в себя шесть крупных месторождений угля: Каа-Хемское, Ээрбекское, Элегестское, Межегейское, Совхозное и Чихачева, а также пять обособленных: Ак-Тальское, Ий-Тальское, Онкажинское, Чаданское и Чангыс-Хадынское.

Геологические исследования способствовали систематизации геологических знаний, послужили толчком к росту изученности территории Тувы и вовлечения в хозяйственное использование минерально-сырьевых ресурсов региона. Возможности использования минерально-сырьевого потенциала Республики Тыва изучали В. И. Лебедев, К. С. Кужугет, геолого-экономический анализ с оценкой инвестиционного потенциала каменных углей подготовлен В. И. Лебедевым (Лебедев, Кужугет, 1998).

Параллельно с изучением угленосности и определением практической ценности месторождений велась и добыча угля, прежде всего для нужд столицы Тувы - строящегося и развивающегося города Белоцарска (с 1926 г. - города Кызыла). Временной интервал с 1914-го по 1945-й гг. может быть назван периодом кустарного освоения отдельных месторождений: с 1925 г. - Чихачёвского месторождения, с 1938 г. - Эрбекского. На Эрбекском месторождении была заложена первая в Туве угольная шахта, которая работала с 1938 по 1953 г. В 1953 г. произошёл взрыв угольной пыли и возгорание угольного пласта на шахте, погибли 9 человек, поэтому добыча угля была перенесена на Усть-Элегестский участок Элегестского месторождения. Сооружение шахты «Красная горка» на Элегестском месторождении

${ }^{1}$ Гаврилин, К. В., Антонова, Т. Д., Кочуева, Н. Г. (1993) Оценка прогнозных ресурсов ведущих твёрдых полезных ископаемых Красноярского края и Тувинской АССР по состоянию на 01.01.1993 г./геол.отчет. Красноярск: ТФГИ по Сибирскому федеральному округу, № 2191, 148 л. 
началось в 1951 году в посёлке Усть-Элегест. В течение 1951 г. здесь было добыто 32293 т угля. Позднее была построена новая шахта, взамен первой, оказавшейся малоперспективной. В 1965 г. добыча угля на шахте достигла 320 тысяч тонн. В октябре 1970 г. шахта «Красная горка» на Элегестском месторождении была закрыта в связи с запуском угольных разрезов «Каа-Хемский» и «Чаданский».

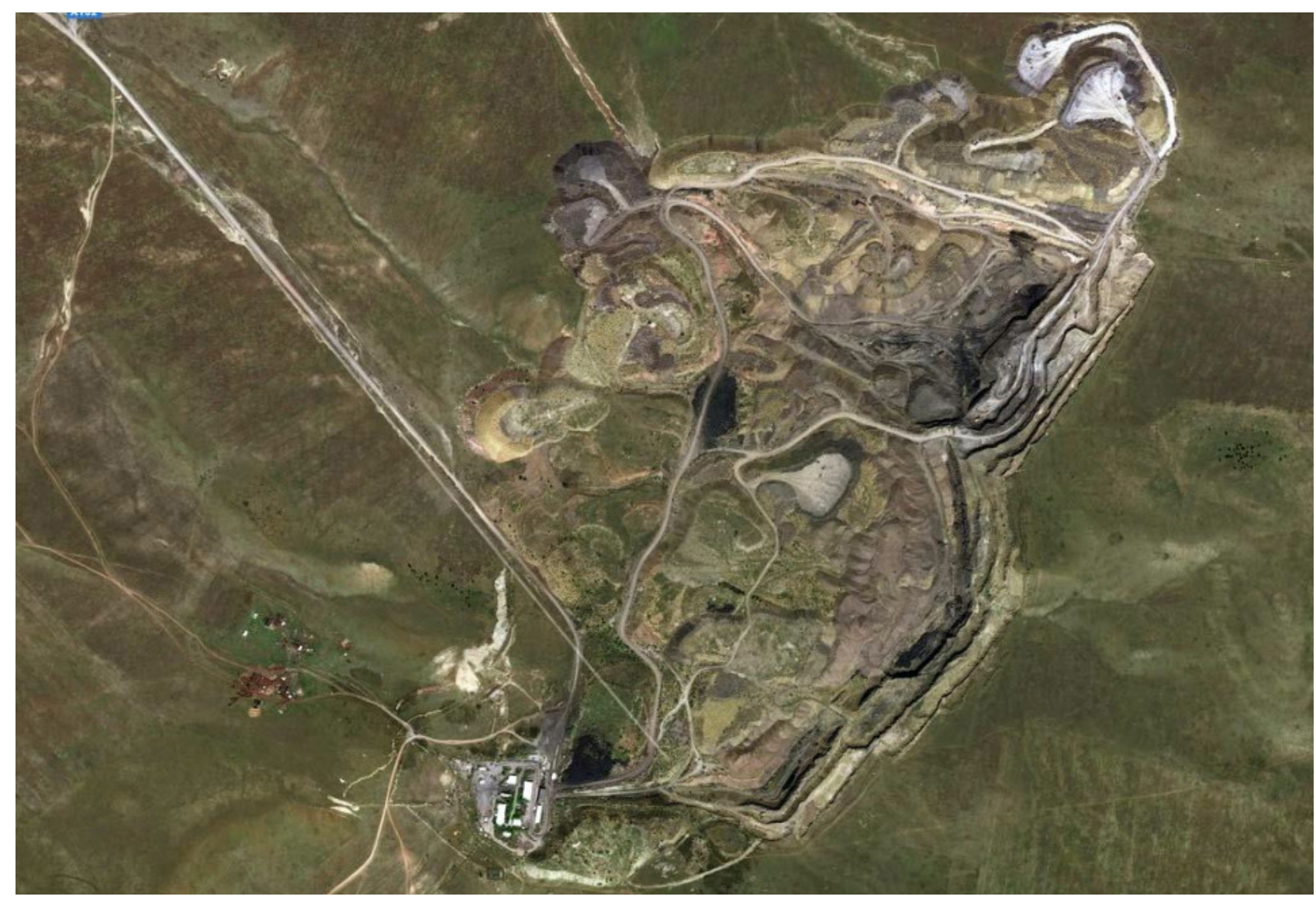

Фото 3. Чаданский угольный разрез, вид из космоса. Космоснимок, сделанный с помощью сервиса www.arcgis.com

Photo 3. Chadan surface coal mine, a photo made via www.arcgis.com

Каа-Хемский угольный разрез является главным поставщиком угля в пределах республики Тыва (Восточная и центральная Тува). Начал свою работу в 1970 г. Чаданское угольное месторождение расположено в Дзун-Хемчикском кожууне Тувы и относится к отдельной Чаданской мульде Улуг-Хемского угольного бассейна. Чаданский угольный разрез расположен в 17 км от города Чадан и в 220 км от города Кызыл. Разработка начата в 1960-е гг. После начала работы Каа-Хемского угольного разреза Чаданский разрез стал структурным звеном нового угледобывающего предприятия. На данный момент принадлежит ООО «Тувинская горнорудная компания», весь добываемый уголь потребляется на западе Республики Тыва.

Основными поставщиками угля в настоящее время являются три предприятия: ООО «Тувинская горнорудная компания» (ТГРК), ООО «УК «Межегейуголь», ООО «Тувинская Энергетическая Промышленная Корпорация» (ТЭПК). ООО «Тувинская горнорудная компания» ведет добычу угля на двух разрезах: Каа-Хемском и Чаданском, где объем добычи составил в 2017 г. - 532,5 тыс. тонн, в 2018 г. 656 тыс. тонн. ООО «УК «Межегейуголь» добывает уголь Межегейского месторождения с объемом добычи в 2017 г. - 880,8 тыс. тонн, в 2018 г. - 1086,1 тыс. тонн угля. ООО «Тувинская Энергетическая Промышленная Корпорация» занимается разработкой Элегестского месторождения с объемом добычи в 2017 г. - 73,7 тыс. тонн, в 2018 г. - 24 тыс. тонн угля. Добываемый уголь реализуется большей частью на местном рынке и используется для выработки тепловой энергии. Часть угля автотранспортом до г. Абакана и далее по железной дороге поступает на металлургические предприятия России и нефтехимические заводы. 


\section{Из истории исследований по переработке каменных углей в Туве}

Изучению и методам технологической переработки минерального сырья Тувы посвящено много исследований тувинских ученых (Коновалов, 1983; Соднам, 1990; Копылов, Каминский, Куликова, 2008; Кара-сал, 2009; Кара-сал, Серен, Монгуш, 2015; Котельников, 2010; Куликова, Балакина, 2019).

Так, исследованием состава и способов переработки аммиачно-карбонатных растворов от выщелачивания кобальтомышьяковых руд занимался Д.Б.Бузур-оол, в 1967 г. он защитил диссертацию в Уральском политехническом институте им. С. М. Кирова (Бузур-оол, 1967).

Научная деятельность Б. К. Кара-сала связана с исследованиями по получению керамических и других строительных материалов из минерального сырья Тувы (Кара-сал, 2009; Кара-сал, Серен, Монгуш, 2015). Т. Х. Самданчап исследовал системы открытой разработки крутопадающих залежей хризотиласбеста, кандидат технических наук (Самданчап, 1971). С. С. Сат изучал возможности развития материальной базы по изготовлению стеновых ограждающих конструкций в Тувинской АССР и др. (Сат, 1970).

Для решения вопросов рационального использования каменных углей сотрудники Тувинского института комплексного освоения природных ресурсов (ТувИКОПР) СО РАН разрабатывали технологии и оборудование высокоэффективной комплексной переработки углей.

Можно выделить три этапа развития этих технологических исследований по переработке углей в регионе и возможные контуры производств по комплексной переработке угля:

- первый этап характеризуется становлениемлаборатории технологий углепереработки (1987-2002);

- второй этапсвязансисследованиями управляемогоизменения свойствугля путём комбинирования методов энергетического и физико-химического воздействия для его активации, разработкой и конструирования нового оборудования для реализации процессов пиролиза, брикетирования каменных углей (2002-2014);

- третий этап развивает эти работы и обосновывает создание углехимического комплекса в Республике Тыва с постепенным переходом на глубокую переработку угля с получением моторных топлив, химических веществ и других ценных продуктов, а также тепловой и электрической энергии (2014 г. по настоящее время).

Рассмотрим эти этапы.

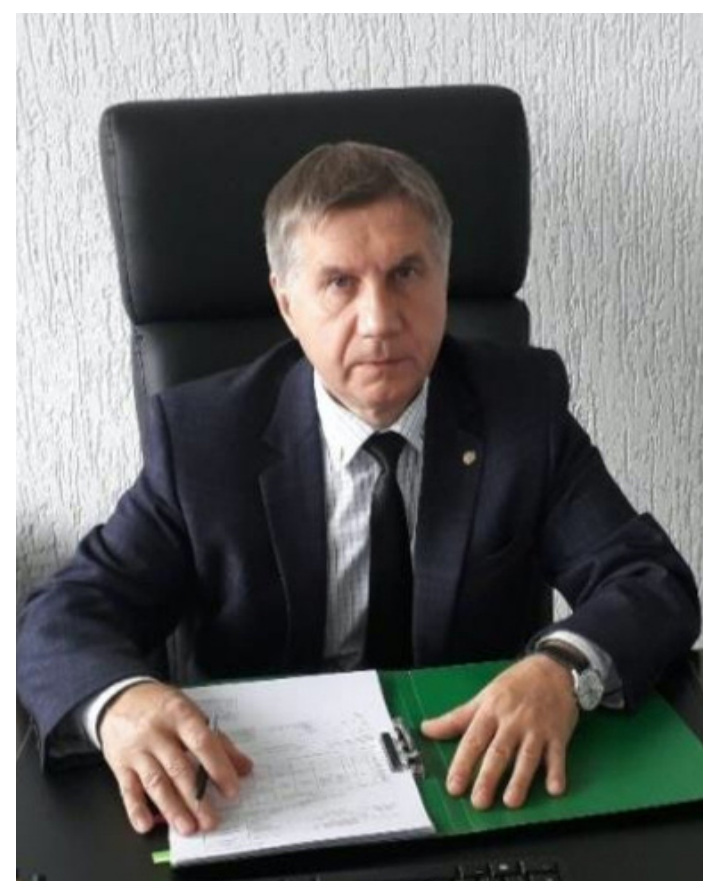

Фото 4. Николай Михайлович Коновалов. Фото предоставлено Н. М. Коноваловым. Photo 4. Nikolai Mikhailovich Konovalov, photo courtesy of himself.
Лаборатория технологий углепереработки в Тувинском комплексном отделе (ТКО) СО АН СССР была создана в 1986 г. Учеными проводились исследования физико-химических, технологических свойств углей региона под руководством заведующего лабораторией технологий углепереработки Н. М. Коновалова и Н. А. Ажищева, первого директора ТКО СО АН СССР, ранее работавшими в Институте химии и химической технологии СО АН СССР (ИХХТ СО РАН) в г. Красноярске. Заведовал лабораторией технологий углепереработки к. тех. н. Н. М. Коновалов (1986-1993). По приглашению Н. А. Ажищева в коллективе начали работать: кандидаты технических наук А. К. Ставаш, А. Ф. Константинов, его однокурсники по ЛТИ им. Ленсовета, кандидаты химических наук Г. С. Яблонский, К. Д. Аракчаа, О. О. Бартан, Л. Х. Тас-оол, О. Е. Ланчикова, А. В. Мышлявцев, Д. Д. Балданова, канд. физ.-мат. н. М. А.-Х. Ондар, канд. геол. н. А. М. Черезов, кандидаты технических наук Т. Х. Самданчап, И. Ф. Дружинкин и др.

Несколько слов о Н. М. Коновалове и его вкладе.

Николай Михайлович Коновалов (фото 4) работал в ТКО СО АН СССР с 1986 по 1993 гг. Под его руководством разработаны научные основы и технология газификации и пиролиза углей, создана экспериментальная установка пиролиза и газификации углей в кипящем слое. Он окончил с отличием в 1978 г. Сибирский технологический институт 
по специальности «Машины и аппараты химических производств» с квалификацией инженера-механика. В 1983 г. окончил аспирантуру Казанского химико-технологического института и защитил диссертацию на соискание учёной степени кандидата технических наук по специальности «Процессы и аппараты химической технологии» (Коновалов, 1983).

Научная деятельность Н. М. Коновалова была связана с изучением гидродинамики, процессов теплои массопереноса в двухфазных газожидкостных системах; разработкой способов получения методами скоростного пиролиза углеродных материалов. За эти годы в лаборатории, которой он руководил, сформировался кадровый и научный потенциал. В разное время в составе творческого коллектива работали Ж. Э. Чоксум, Н. В. Строганова, Л. В. Мышлявцева, Н. Н. Янчат, Н. В. Бурдин, М. П. Куликова, Н. И. Соднам, В. И. Котельников и др. Сотрудники лаборатории занимались исследованием пиролиза и газификации углей Каа-Хемского месторождения, работами по испытанию экспериментальной установки. Конечно, инициатором и мотором всех начинаний и свершений был Н. М. Коновалов. Николай Михайлович стал одним из основоположников научных исследований по направлению глубокой переработки переработке углей тувинского региона.

Развитием работ Н. М. Коновалова стали исследования Ю. Д. Каминского, В. И. Котельникова, М. П. Куликовой, К. К. Чульдум, Г. Р. Монгуш, Ш. Н. Солдуп и др. По теме «Физико-химические особенности термохимических превращений газовых углей Каа-Хемского месторождения» в 1990 г. защитила диссертацию на соискание ученой степени кандидата технических наук Н. И. Соднам (Соднам, 1990). В 1993 г. М. П. Куликова защитила кандидатскую диссертацию на соискание ученой степени кандидата химических наук по специальности «Коллоидная и мембранная химия» (Куликова, 1993).

С 1995 г. Н. М. Коновалов работал главным механиком, заместителем начальника управления, начальником управления (по товарно-транспортным операциям) филиала «Красноярское районное нефтепроводное управление» ОАО «Транссибнефть», где и работает по настоящее время. Труд Николая Михайловича отмечен наградами: благодарностью Министерства энергетики Российской Федерации (2001), Почетной грамотой Сибирского регионального центра по делам ГО, ЧС и ЛПСБ (2009), Почетной грамотой Министерства энергетики РФ (2013), почетным званием «Почетный нефтяник» (2017).

Второй этап развития направлений комплексной переработки углей в регионе связан с научным направлением, зародившимся из физической химии и химии твёрдого тела, - механохимии. Основная идея механохимических технологий заключается в том, что на основании твердотельных механохимических реакций можно управлять свойствами твердых тел и повышать степень извлечения ценных компонентов. В 2002 г. в ТувИКОПР СО РАН была создана лаборатория геотехнологий освоения месторождений (ГЕОТОМ), имеющая статус подразделения двойного подчинения: ТувИКОПР СО РАН + ИХТТМ СО РАН. Заведовал лабораторией ГЕОТОМ в 2002-2014 гг. кандидат технических наук Юрий Дмитриевич Каминский. Под его руководством проводились исследования по теме «Управляемые изменения свойств минерального сырья путём комбинирования методов энергетического и физико-химического воздействия для вскрытия и активации руд и твёрдого топлив». Научная деятельность Ю.Д. Каминского была связана с исследованием механических и механохимических методов активации руд и твёрдого топлива, проблемы химико-технологической переработки сырья цветных, редких и благородных металлов; разработкой механохимических, автоклавных процессов и аппаратурным оформлением их реализации. Сотрудники ТувИКОПР СО РАН совместно с ИХТТМ СО РАН и другими соисполнителями под его руководством (Н. И. Копылов, А. В. Полугрудов, Н. В. Бурдин, К. К. Чульдум, Р. О. Молдурушку, Х. Б. Манзырыкчы и др.) разработали трубчатую автоклавную установку высокотемпературного выщелачивания для переработки минерального и техногенного сырья. На основе результатов теоретических и экспериментальных исследований были обоснованы принципы конструирования нового оборудования для реализации процессов пиролиза и брикетирования углей, определены алгоритмы оптимального управления процессом, позволяющие регулировать параметры пиролиза углей. С 2014 г. и по настоящее время Ю. Д. Каминский работает старшим научным сотрудником лаборатории интеркаляционных и механохимических реакций института химии твёрдого тела и механохимии СО РАН (ИХТТМ СО РАН) в г. Новосибирск.

На третьем этапе исследований работы продолжаются: обосновывается создание углехимического комплекса в Республике Тыва с постепенным переходом на глубокую переработку угля. Это исследования В. И. Котельникова, К. К. Чульдум и др., связанные с использованием основного принципа шнекового реактора - термического разложения угля в среде летучих продуктов в условиях сжатия, изучением высокоэффективных способов получения методами скоростного пиролиза углеродных материалов различного назначения. С 2014-2016 гг. заведовал лабораторией химико- 


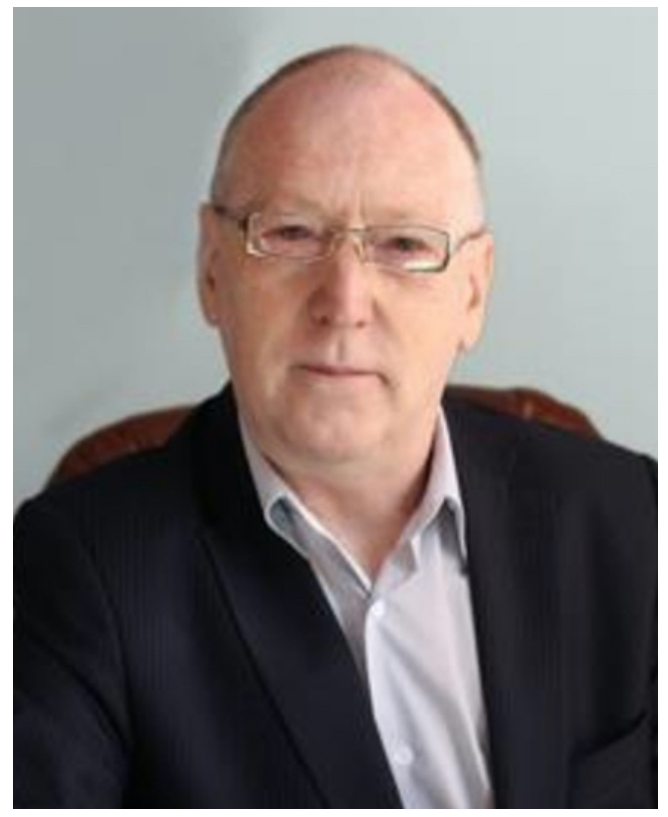

Фото 5. Директор Тувинского института комплексного освоения природных ресурсов СО РАН Валерий Ильич Котельников.

Фото предоставлено В. И. Котельниковым. Photo 5. Director of Tuvinian Institute for Exploration of the Natural Resources, Siberian Branch, Russian Academy of Sciences Valery Il'ich Kotelnikov. Photo courtesy of himself.

\section{В. И. Котельникова).}

В настоящее лабораторией с 2017 г. заведует кандидат химических наук Тас-оол Любовь Хертековна. Проводятся исследования по научному проекту «Исследование ресурсо- и энергосберегающих химико-технологических процессов углубленной переработки углеводородного и минерального сырья, техногенных отходов» (с 2016-2020 гг.) совместно с лабораторией материаловедения.

В составе химико-технологической лаборатории ${ }^{1}$ трудятся: к. х. н. Л.Х. Тас-оол, к. Х. н. М.П. Куликова, н. с. Н. Н. Янчат, м. н. с. Г. Р. Монгуш, м. н. с. Ш. Н. Солдуп, м. н. с. С. А. Ондар; заведующий сектором Х. Б. Манзырыкчы, ведущий инженер Е. Н. Тимошенко (фото 6).

В лаборатории проводятся исследования по технологиям переработки тувинских углей, по геохимии органического и неорганического вещества углей, по мониторингу загрязнения атмосферы г. Кызыла выбросами от сжигания углей. Сложился дружный и творческий коллектив, который имеет тесные связи с учеными Тувинского государственного университета, Тувинского Научного центра, Красноярского, Новосибирского, Кемеровского научных центров Сибирского отделения Российской академии наук (Института химии и химической технологии СО РАН, Института химии твердого тела и механохимии СО РАН, Института угля СО РАН, Института углехимии и материаловедения СО РАН). Также исследователи сотрудничают с учеными зарубежных научных центров (Вашингтонского университета, Сент-Луис, США), Института геологии Геологической академии, Китай, Института геологии и минеральных ресурсов Академии наук Монголии), а также со специалистами ведущих угольных предприятий: «Тувинской горнорудной компании», УК «Межегейуголь» и др. Сотрудники принимают активное в международных форумах и выставках (Технопром-2018, RENWEX-2019 и др.), научные разработки сотрудников лаборатории неоднократно были отмечены наградами и дипломами.

\section{Заключение}

В статье показано становление науки об истории исследований на основе двух взаимосвязанных процессов: изучения истории исследований каменных углей в Туве и истории исследования про- 


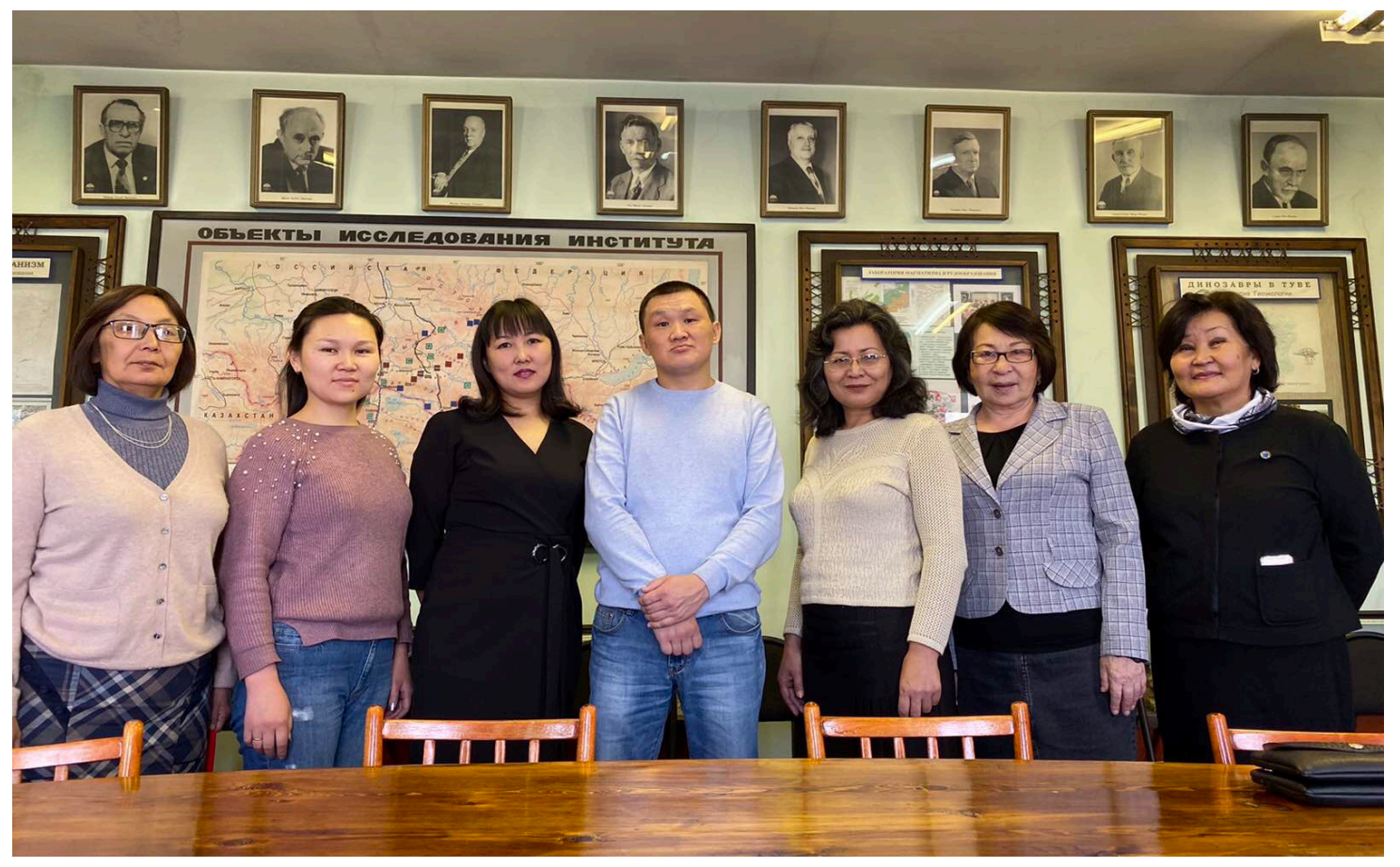

Фото 6. Коллектив лаборатории химико-технологических процессов. Фото 2020 г. Ю. Ю. Самбыла.

Photo 6. Staff members of the Laboratory of Processes in Chemical Engineering, 2020. Photo by Yu. Yu. Sambyla.

блем их переработки. История открытия и освоения угля в Туве неразрывно связана с историей развития технологических процессов: первый период (1879-1892 гг.) связан с накоплением первых географических и геологических сведений о Туве; во второй период (1903-1944 гг.) проводятся экспедиционные исследования, установившие основные черты геологии региона; в третий период (1944 - начало 1990-х гг.) разворачиваются планомерные поисковые и разведочные работы на уголь. Систематизация геологических знаний о каменных углях способствовала вовлечению углей в практическое использование и технологическим исследованиям проблем их переработки. Выделены три этапа развития технологических исследований по переработке углей в регионе. Несмотря на все разнообразие направлений использования ископаемых углей основным их потребителем в Республике Тыва до сих пор являются теплоэнергетика и жилищно-бытовой сектор. Небольшая часть угля автотранспортом до г. Абакана и далее по железной дороге поступает на металлургические предприятия России и нефтехимические заводы.

Будущее использование тувинских углей связано с развитием инновационных технологий обогащения угля с постепенным переходом на его глубокую переработку. У тувинских ученых есть собственные разработки в области технологий их переработки. За сравнительно короткий период с 1986 по 2020 гг. учеными ТувИКОПР СО РАН проведены исследования физико-химических, технологических свойств углей Каа-Хемского месторождения, создана и испытана установка пиролиза и газификации каменных углей в кипящем слое, получены авторские свидетельства и патенты на создание установки для пиролиза углей экструзивного типа, проведены исследования управляемого изменения свойств угля путём комбинирования методов энергетического и физико-химического воздействия для его активации, разработано новое оборудование для реализации процессов пиролиза, брикетирования каменных углей. Итогом научных разработок стало обоснование создания углехимического комплекса в Республике Тыва с постепенным переходом на глубокую переработку угля с получением моторных топлив, химических веществ и других ценных продуктов, а также экологически чистой тепловой и электрической энергии. Развитие этого направления угольной промышленности имеет неограниченные перспективы для создания горно-металлургического и углехимического комплекса в Республике Тыва. 


\section{СПИСОК ЛИТЕРАТУРЫ}

Адрианов, А. В. (1888) Путешествие на Алтай и за Саяны, совершённое в 1881 г. по поручению Императорского Русского географического общества / Записки ИРГО по общей географии. СПб.: Тип. Имп. Акад. наук, Т. XI. 444 с.

Балакина, Г. Ф., Куликова, М. П. (2019) Инструменты регулирования развития углепромышленной территории в регионе // Уголь. № 12. С. 32-37. DOI: http:/dx.doi.org/10.18796/0041-5790-2019-12-32-36

Бузур-оол, Д. Б. (1967) Изучение состава и способов переработки аммиачно-карбонатных растворов от выщелачивания кобальтомышьяковых руд : автореф. дисс. ... канд. техн. наук. Свердловск. 22 с.

Государственный баланс запасов полезных ископаемых РФ на 01.01.2007 г. Вып. 91. Уголь. Т. VII, Кызыл : Тывинский филиал ФБУ «ТФГИ по Сибирскому федеральному округу». № 594.124 с.

Грумм-Гржимайло, Г. Е. (1914) Западная Монголия и Урянхайский край : в 3 т. СПб. : Невская типография. Т. 1. Описание природы этих стран. 569 с.

Дабиев, Д. Ф. (2013) Состояние и перспективы угледобычи в Туве [Электронный ресурс] // Новые исследования Тувы. № 4. C. 144-150. URL: https://nit.tuva.asia/nit/article/view/207 (дата обращения: 10.02.2020).

Зайцев, А. М. (1896) Петрографический материал, собранный П. Н. Крыловым в 1892 году на Саянах и в Урянхайской земле. Томск : Тип. П. И. Макушина. 23 с.

Копылов, Н. И., Каминский, Ю. Д., Куликова, М. П. (2008) Пиролиз угля Тувинского месторождения // Химическая технология. Т. 9. № 4. С. 168-173.

Кара-сал, Б. К. (2009) Минеральное сырье Тувы для производства строительных материалов. Кызыл : Ред-издат. отдел ТывГУ. 169 с.

Кара-сал, Б. К., Серен, Ш. В., Монгуш, Д. С. (2015) Получение плотноспеченных керамических изделий с применением полевошпатцеолитового сырья Тувы // Стекло и керамика. № 9. С. 28-31.

Коновалов, Н. М. (1983) Гидродинамика и массообмен в условиях прямоточного движения газа и пленки жидкости : автореф. дис. ... канд. техн. наук. Казань. 17 с.

Котельников, В. И. (2010) Разработка конструкции малогабаритного устройства непрерывного пиролиза твердого органического топлива в термически нагруженном слое : автореф дис. ... канд. техн. наук. Барнаул. 18 с.

Кузнецов, В. А. (1946) Новые данные по геологии Тувы // Известия Академии Наук СССР. Серия геологическая. № 5. С. 91-105.

Крылов, П. А. (1903) Путевые заметки об Урянхайской земле / Записки ИРГО по общей географии. СПб.: Типография императорской академии наук, Т. 34, № 2.166 с.

Куликова, М. П. (1993) Исследование адсорбционной и эмульгирующей способности высокомолекулярных поверзностно-активных веществ : автореф. дисс. ... канд. хим. наук. СПб. 18 с.

Куликова, М. П., Балакина, Г. Ф. (2019). Перспективы развития углеперерабатывающих производств в Республике Тыва // Уголь. № 11. С. 15-20. DOI: http:/dx.doi.org/10.18796/0041-5790-2019-11-15-18

Кызласов, Л. Р. (1969) История Тувы в средние века. М. : Изд-во МГУ. 214 с.

Лебедев, Н. И. (2007) Угли Тувы: состояние и перспективы освоения сырьевой базы. Кызыл : ТувИКОПР СО РАН. $180 \mathrm{c}$.

Лебедев, В. И., Кужугет, К. С. (1998) Минерально-сырьевой потенциал Республики Тыва: возможность его использования в 1999-2001 гг. и перспективы дальнейшего освоения. Кызыл: ТувИКОПР СО РАН. 28 с.

Обручев, В.А.(1917) Обзор путешествий Д.А.Клеменца по Внутренней Азии и их геологических и географических результатов // Известия Восточно-Сибирского Отдела Императорского Русского географического общества. T. XLV. C. $1-34$.

Обручев, В. А. (2007) Естественные богатства Танну-Тувинской республики и степень изученности последней // Урянхай. Тыва дептер / составитель С. К. Шойгу : в 7 т. М. : Слово/Slovo. Т. 6. 584 с. С. 164-179.

Потанин, Г. Н. (1883) Очерки Северо-Западной Монголии. Вып. 3. СПб. : Тип. В. Безобразова и К․ 385 с.

Рачковский, И. П., Педашенко, А. И. (1918) О командировке с целью подготовки материала для выработки плана систематической геологической съёмки и осмотра месторождений полезных ископаемых в Урянхайском крае: Отчёт Геологического комитета в 1917 г. // Известия Геологического Комитета. Т. 37. С. 219-226.

Рачковский, И. П. (1920) Отчет о деятельности Сибирского отделения Геологического комитета за 1920 г // Известия Сибирского Отделения Геологического комитета. T. IV, Вып. 6. С. 118-131.

Родевич, В. М. (1912) Урянхайский край и его обитатели / Известия Императорского Русского географического общества. СПб. : Типография М. М.Стасюлевича. 60 с.

Самданчап, Т. Х. (1971) Исследование систем открытой разработки крутопадающих залежей хризотил-асбеста : автореф. дисс. ... канд. техн. наук. М. 17 с.

Сат, С. С. (1970) Определение оптимальных типов стеновых ограждающих конструкций в условиях Тувинской АССР с учетом возможностей развития материальной базы по их изготовлению : автореф. дисс.... канд. техн. наук. M. 13 c. 
Смирнова, Н. Н. (1912) Растительные остатки из Ursa-stufe (медвежьевого яруса) реки Улу-Кем // Труды СанктПетербургского общества естествоиспытателей Отделение геологии и минералогии. Т. 35. Вып. 5. С. $137-144$.

Соднам, Н. И. (1990) Физико-химические особенности термохимических превращений газовых углей КааХемского месторождения : автореф. дисс.... канд. техн. наук. Красноярск. 18 с.

Соян М. К. (2006) Оценка эффективности развития производственного комплекса и его влияния на социальноэкономическое состояние региона: на примере освоения угольных месторождений Республики Тыва : автореф. дисс. .... канд. экон. наук. Новосибирск. 17 с.

Соян, Ш. Ч. (2019) Особенности развития и проблемы угольной отрасли // Уголь. № 11. C. 12-15. DOI: http:/ dx.doi.org/10.18796/0041-5790-2019-10-12-14

Обручев, В. А. (2007) Естественные богатства Танну-Тувинской республики и степень изученности последней // Урянхай. Тыва дептер / составитель С. К. Шойгу : в 7 т. М. : Слово/Slovo. T. 6. 584 с. . 164-179.

Шишкин, Б. К. (1914) Очерки Урянхайского края. Томск : Типо-литография Сибирского товарищества печатного дела. 327 с.

Schmalhausen, J. (1883) Pflanzenpaläontologische Beiträge. I. Nachträge zur Jura-Flora des Kohlenbeckens von Kusnetzk im Altai. II. Pflanzenreste aus der Nordwestlichen Mongolei / Memoires Res L’Academie Imperiale des Sciences. De St-Petersbourg: imprimerie de L’Academie Imperiale des Sciences. 7 Serie, T. 31. P. 545-563.

Дата поступления: 12.02.2020 г.

\section{REFERENCES}

Adrianov, A. V. (1888) Puteshestvie na Altai i za Saiany, sovershennoe v 1881 g. po porucheniiu Imperatorskogo Russkogo geograficheskogo obshchestva [Travel to the Altai and beyond the Sayans, made in 1881 on behalf of the Imperial Russian geographical society] / Zapiski IRGO po obshchei geografii. St. Petersburg, Tip. Imp. Akad.nauk, T. XI. 444 p. (In Russ).

Balakina, G. F., Kulikova, M. P. (2019) Instrumenty regulirovaniia razvitiia uglepromyshlennoi territorii v regione [Tools for regulating the development of the coal industry in the region]. Ugol', no. 12, pp. 32-37. (In Russ). DOI: http:/ dx.doi.org/10.18796/0041-5790-2019-12-32-36

Buzur-ool, D. B. (1967) Izuchenie sostava i sposobov pererabotki ammiachno-karbonatnykh rastvorov ot vyshchelachivaniia kobal'tomysh'iakovykh rud [A study of the composition and methods of processing of ammonia-carbonate solutions from leaching of cobalt-arsenic ores] : Thesis of Diss.... Candidate of Technical science. Sverdlovsk. 22 p. (In Russ).

Gosudarstvennyi balans zapasov poleznykh iskopaemykh RF na 01.01.2007 g. Vyp. 91. Ugol' [State balance of mineral resources of the Russian Federation for 01.01.2007 Issue 91. Coal] Vol. VII. Kyzyl, Tyvinskii filial FBU «TFGI po Sibirskomu federal'nomu okrugu». No. 594. 124 p. (In Russ).

Grumm-Grzhimailo, G. E. (1914) Zapadnaia Mongoliia i Uriankhaiskii krai [Western Mongolia and the Uriankhai Territory] : in 3 vols. St. Petersburg, Nevskaia tipografiia. Vol. 1. Opisanie prirody etikh stran. 569 p. (In Russ).

Dabiev, D. F. (2013) Sostoianie i perspektivy ugledobychi v Tuve [Status and prospects of coal mining in Tuva]. The New Research of Tuva, no. 4, pp. 144-150 [online] Available at: URL: https://nit.tuva.asia/nit/article/view/207 (access date: 10.02.2020). (In Russ).

Zaitsev, A. M. (1896) Petrograficheskii material, sobrannyi P. N. Krylovym v 1892 godu na Saianakh $i$ v Uriankhaiskoi zemle [Petrographic material collected by P. N. Krylov in 1892 in the Sayans and Uriankhai land]. Tomsk, Tip. P. I. Makushina. 23 p. (In Russ).

Kopylov, N. I., Kaminskii, Yu. D., Kulikova, M. P. (2008) Piroliz uglia Tuvinskogo mestorozhdeniia [Pyrolysis of coal from the Tuva Deposit]. Khimicheskaia tekhnologiia, vol. 9, no. 4. S. 168-173. (In Russ).

Kara-sal, B. K. (2009) Mineral'noe syr'e Tuvy dlia proizvodstva stroitel'nykh materialov [Mineral raw materials of Tuva for the production of construction materials]. Kyzyl, Red-izdat. otdel TuvGU. 169 p. (In Russ).

Kara-sal, B. K., Seren, Sh. V. and Mongush, D. S. (2015) Poluchenie plotnospechennykh keramicheskikh izdelii s primeneniem polevoshpattseolitovogo syr'ia Tuvy [Obtaining dense-baked ceramic products with the use of Tuva feldspar]. Steklo i keramika, no. 9, pp. 28-31. (In Russ).

Konovalov, N. M. (1983) Gidrodinamika i massoobmen v usloviiakh priamotochnogo dvizheniia gaza i plenki zhidkosti [Hydrodynamics and mass transfer in the conditions of direct flow motion of gas and liquid film] : Thesis of Diss.... Candidate of Technical science. Kazan'. 17 p. (In Russ).

Kotel'nikov, V. I. (2010) Razrabotka konstruktsii malogabaritnogo ustroistva nepreryvnogo piroliza tverdogo organicheskogo topliva $v$ termicheski nagruzhennom sloe [Development of the design of a small-sized device for continuous pyrolysis of solid organic fuel in a thermally loaded layer] : Thesis of Diss.... Candidate of Technical science. Barnaul. 18 p. (In Russ).

Kuznetsov, V. A. (1946) Novye dannye po geologii Tuvy [New data on the Geology of Tuva]. Izvestiia Akademii Nauk SSSR. Seriia geologicheskaia, no. 5, pp. 91-105. (In Russ).

Krylov, P. A. (1903) Putevye zametki ob Uriankhaiskoi zemle [Travel notes on the Uriankhai land] / Zapiski IRGO po obshchei geografii [Notes of the irgo on General geography]. St. Petersburg, Tipografiia imperatorskoi akademii nauk. Vol. 34, no 2.166 p. (In Russ). 
Kulikova, M. P. (1993) Issledovanie adsorbtsionnoi i emul'giruiushchei sposobnosti vysokomolekuliarnykh poverznostno-aktivnykh veshchestv [A study of adsorption and emulgation capabilities of highly molecular and surface active agents]: Thesis of Diss.... Candidate of Chemical science. St. Petersburg. 18 p. (In Russ).

Kulikova, M. P. and Balakina, G. F. (2019) Perspektivy razvitiia uglepererabatyvaiushchikh proizvodstv v Respublike Tyva [Prospects for the development of coal processing industries in the Republic of Tuva]. Ugol', no. 11, pp. 15-20. (In Russ). DOI: http:/dx.doi.org/10.18796/0041-5790-2019-11-15-18 Russ).

Kyzlasov, L. R. (1969) Istoriia Tuvy v srednie veka [History of Tuva in the middle ages]. Moscow, Izd-vo MGU. 214 p. (In

Lebedev, N. I. (2007) Ugli Tuvy: sostoianie i perspektivy osvoeniia syr'evoi bazy [Coal of Tuva: state and prospects of development of the raw material base]. Kyzyl, TuvIKOPR SO RAN. 180 p. (In Russ).

Lebedev, V. I. and Kuzhuget, K. S. (1998) Mineral'no-syr'evoi potentsial Respubliki Tyva: vozmozhnost' ego ispol'zovaniia $v$ 1999-2001 gg. i perspektivy dal'neishego osvoeniia [Mineral resource capability of the Republic of Tuva: the possibility of its use in 1999-2001 and prospects for further development]. Kyzyl, TuvIKOPR SO RAN. 28 p. (In Russ).

Obruchev, V. A. (1917) Obzor puteshestvii D. A. Klementsa po Vnutrennei Azii i ikh geologicheskikh i geograficheskikh rezul'tatov [Review of D. A. Klemenz's travels in Inner Asia and their geological and geographical results]. Izvestiia Vostochno-Sibirskogo Otdela Imperatorskogo Russkogo geograficheskogo obshchestva, vol. XLV, pp. 1-34. (In Russ).

Obruchev, V. A. (2007) Estestvennye bogatstva Tannu-Tuvinskoi respubliki i stepen' izuchennosti poslednei [Natural resources of the Tannu-Tuva Republic and the degree of study of the latter]. In: Uriankhai. Tyva depter [Uriankhai. Tuvan notebooks] / comp. by S. K. Shoigu : in 7 vol. Moscow, Slovo/Slovo. Vol. 6. 584 p. Pp. 164-179. (In Russ).

Potanin, G. N. (1883) Ocherki Severo-Zapadnoi Mongolii [Essays Of North-Western Mongolia]. Vol. 3. St. Petersburg, Tip. V. Bezobrazova i $\mathrm{K}^{\circ} .385$ p. (In Russ).

Rachkovskii, I. P. and Pedashenko, A. I. (1918) O komandirovke s tsel'iu podgotovki materiala dlia vyrabotki plana sistematicheskoi geologicheskoi s"emki i osmotra mestorozhdenii poleznykh iskopaemykh v Uriankhaiskom krae: Otchet Geologicheskogo komiteta v 1917 g. [On a field trip to prepare material for the development of a plan for systematic geological survey and inspection of mineral deposits in the Uriankhai Territory: Report of the Geological Committee in 1917]. Izvestiia Geologicheskogo Komiteta, vol. 37, pp. 219-226. (In Russ).

Rachkovskii, I. P. (1920) Otchet o deiatel'nosti Sibirskogo otdeleniia Geologicheskogo komiteta za 1920 g. [Report on the activities of the Siberian branch of the Geological Committee for 1920]. Izvestiia Sibirskogo Otdeleniia Geologicheskogo komiteta, vol. IV, issue 6, pp. 118-131. (In Russ).

Rodevich, V. M. (1912) Uriankhaiskii krai i ego obitateli [Uriankhai Territory and its inhabitants] / Izvestiia Imperatorskogo Russkogo geograficheskogo obshchestva. St. Petersburg, Tipografiia M. M.Stasiulevicha. 60 p. (In Russ).

Samdanchap, T. Kh. (1971) Issledovanie sistem otkrytoi razrabotki krutopadaiushchikh zalezhei khrizotil-asbesta [Investigation of open-pit mining systems for steep-falling chrysotile-asbestos deposits] : Thesis of Diss. ... Candidate of Technical science. Moscow. 17 p. (In Russ).

Sat, S. S. (1970) Opredelenie optimal'nykh tipov stenovykh ograzhdaiushchikh konstruktsii v usloviiakh Tuvinskoi ASSR $s$ uchetom vozmozhnostei razvitiia material'noi bazy po ikh izgotovleniiu [Determination of optimal types of wall enclosing structures in the conditions of the Tuvan ASSR, taking into account the possibilities of developing the material base for their production] : Thesis of Diss.... Candidate of Technical science. Moscow. 13 p. (In Russ).

Smirnova, N. N. (1912) Rastitel'nye ostatki iz Ursa-stufe (medvezh'evogo iarusa) reki Ulu-Kem [Plant remains from the Ursa-stufe (bear tier) of the Ulu-Kem river]. Trudy Sankt-Peterburgskogo obshchestva estestvoispytatelei Otdelenie geologii $i$ mineralogii, vol. 35, issue 5, pp. 137-144. (In Russ).

Sodnam, N. I. (1990) Fiziko-khimicheskie osobennosti termokhimicheskikh prevrashchenii gazovykh uglei Kaa-Khemskogo mestorozhdeniia [Physical and chemical features of thermochemical transformations of gas coals of the Kaa-Khem Deposit] : Thesis of Diss.... Candidate of Technical science. Krasnoiarsk. 18 p. (In Russ).

Soyan M. K. (2006) Otsenka effektivnosti razvitiia proizvodstvennogo kompleksa i ego vliianiia na sotsial'no-ekonomicheskoe sostoianie regiona: na primere osvoeniia ugol'nykh mestorozhdenii Respubliki Tyva [Evaluation of the efficiency of the industrial complex development and its impact on the socio-economic state of the region: on the example of the development of coal deposits in the Republic of Tuva] : Thesis of Diss.... Candidate of Economical science. Novosibirsk. 17 p. (In Russ).

Soyan, Sh. Ch. (2019) Osobennosti razvitiia i problemy ugol'noi otrasli [The features and problems of the coal mining industry in the Republic of Tuva]. Ugol', no. 11, pp. 12-15. DOI: http:/dx.doi.org/10.18796/0041-5790-2019-10-12-14

Obruchev, V. A. (2007) Estestvennye bogatstva Tannu-Tuvinskoi respubliki i stepen' izuchennosti poslednei [Natural resources of the Tannu-Tuva Republic and the degree of study of the latter]. In: Uriankhai. Tyva depter [Uriankhai. Tuvan notebook] / comp. by S. K. Shoigu : in 7 vol. Moscow, Slovo/Slovo. Vol. 6. 584 p. Pp. 164-179. (In Russ).

Shishkin, B. K. (1914) Ocherki Uriankhaiskogo kraia [Essays of the Uriankhai region]. Tomsk, Tipo-litografiia Sibirskogo tovarishchestva pechatnogo dela. 327 p. (In Russ).

Schmalhausen, J. (1883) Pflanzenpaläontologische Beiträge. I. Nachträge zur Jura-Flora des Kohlenbeckens von Kusnetzk im Altai. II. Pflanzenreste aus der Nordwestlichen Mongolei / Memoires Res L'Academie Imperiale des Sciences. De StPetersbourg: imprimerie de L’Academie Imperiale des Sciences. 7 Serie, Vol. 31. Pp. 545-563. (In Germ.)

Submission date: 12.02 .2020 . 